Linnean Society of London and of the Mammal Society, would wish him to be remembered. We have no doubt that other societies, such as the Zoological Society of London, would wholeheartedly support this tribute.

Lord Cranbrook's schooling as a naturalist with a world-wide field of interest began in the Far East in association with such pioneers as Kingdon Ward. Thereafter he was deeply committed to the furtherance of field biological studies in Great Britain.

For over 46 years he laboured on behalf of our oldest biological society, the Linnean Society of London, which has always acted as a fruitful meeting ground for amateurs (of which he was an outstanding example) and professionals. He served on its Council for 14 years and was Treasurer for 12 years. His astute business sense, combined with his robust common sense, proved invaluable to the Society during its special appeal for funds in 1969. As a result of this appeal, the Linnean Society was able to rehouse and adequately curate its unique collections of plants and animals on which Linneaus once worked; a service which was appreciated by scientists throughout the world.

Lord Cranbrook's enthusiasm, energy and eminence among his wide contacts put him in a unique position to foster progress. Nobody appealed to him in vain for advice and it was always given widely, humorously and forcibly.

Compared with the Linnean, the Mammal Society is a relative newcomer with no valuable collections to house and curate. Lord Cranbrook was a founder member in 1954 and, as its assiduous President, guided the Society in its formative years. It was rare for him to miss a council meeting and each year, when he presided over the Annual General Meeting, there was keen speculation as to whether he could cut ten minutes off his previous record for its speedy completion. Nevertheless, there was no skimping and his grasp of essentials, together with his succinct exposition, gave every point due consideration.

As a Trustee of the British Museum (Natural History) between 1963 and 1973, he again provided a valuable link between the naturalists at large and the more circumscribed specialists.

Lord Cranbrook was a valued speaker in the House of Lords: valued especially because of the reliability of his 'homework' and the clarity and force with which he dealt with complex and controversial matters. All naturalists must be grateful for his pilotage during recent years, when he faced increasing disability with great courage, of the Conservation of Wild Creatures and Wild Plants Act 1975.
He contributed numerous publications to scientific journals, of which the most outstanding was his study of a population of noctule bats which came to feed on crickets at a local rubbish dump. Capturing and marking them with the aid of mist-nets was a notable achievement at that time (1965, Proc. zool. Soc. Lond. 144: 1-24).

Lord Cranbrook's cheerful presence and leadership will be sorely missed throughout the ranks of naturalists and biologists.

P. H. Greenwood H. N. Southern

\section{Jean Clark Dan}

Jean Clark Dan died of asthma in Tateyama, Japan on 13 November 1978, at age 68. Born and reared in a staunchly Presbyterian family in Westfield, New Jersey, USA, she graduated from Wilson College (1932), and continued study under L. V. Heilbrunn at the University of Pennsylvania and in summer at the Marine Biological Laboratory, Woods Hole. On obtaining her PhD (1936) she married Katsuma Dan who had also received his $\mathrm{PhD}$ (1934) with Heilbrunn. They proceeded to Japan via Europe with a stay at the Stazione Zoologica of Naples. Eventually they settled in Tokyo but their early years included long periods at the Misaki Marine Biological Station of Tokyo University.

The Dans produced five children, whose upbringing overlapped World War II. Jean had to move away from home territory but adapted cheerfully, and despite many hardships the whole family managed to survive. Then she undertook multifarious enterprises to surmount postwar adversity: one negotiation utilized army garbage for village rehabilitation while preserving self-respect all around. And she doggedly struggled back to the scientific world.

In 1947 she revisited Woods Hole (to which she would often again return as to another home) where peacetime activities had been re-established. With help from the American Philosophical Society she took a phase contrast microscope back to Japan where, under the wing of Tokyo Metropolitan University, she set up at Misaki a research program on fertilization of marine invertebrates. Publication soon followed. The papers became increasingly important. Her first two 'Studies on the Acrosome' (1952, 1954) demonstrated how the tip of the spermatozoon changes under various conditions, and introduced the term acrosome reaction. She was a pioneer in examining such material with the electron microscope. Some workers were slow to accept her findings but her mounting evidence, together with that of others, firmly established that the reaction does indeed occur. There followed many other important papers. She explored the sperm lysin problem. Much of her later observation and speculation centered around 'dynamic morphology' (precursors, triggers, etc.) of membranous and other parts of the region she came to call the acrosomal complex.

She won grants and fellowships from sources in both countries, received her Japanese $\mathrm{PhD}$, was given the award (1958) of the Zoological Society of Japan, and found herself in international demand for lectures and conferences on spermatology and fertilisation. She was on the editorial board of Development, Growth and Differentiation.

Jean was appointed Lecturer (1959), then Professor (1973) at Ochanomizu University where she taught and supervised graduate students. Interested in that University's Tateyama Marine Biological Station from its inception, she became Director (1975), and planned to spend much of her time at Tateyama after retiring from the University (1976).

During the war Jean had come to speak fluent Japanese. As Japanese biologists returned to research and writing many sought her help with English usage. For years she devotedly helped transform their texts into English suitable for publication. She translated into English Osada's Children of the A-Bomb (1959, with $\mathrm{R}$. Sieben-Morgen), and Invertebrate Embryology (1968, eds. M. Kumé and K. Dan). Moreover, she assisted in the English translation of publications of His Majesty, Emperor Hirohito.

The above barely suggests the warm vital Jean Dan. She was a strong swimmer, walked well, liked to gather wild mushrooms or buy a warm sweetpotato from a street vendor. She liked having a dog. Her children enjoyed a whole family of Siamese cats. In her laboratory would be a flower in a beaker, an attractive picture on the wall. She enthusiastically espoused causes as great as world peace, and with equal vigor would propel a specific student into opportunities for advanced study. Jean was seldom at a loss for words; also, her penchant for friendly listening to and advising others knew no barrier in age, sex or nationality, discipline or problem.

She will be missed as a scientistand as a person. 